\title{
Comparison of the efficacy of preservative free ipratropium bromide and Atrovent nebuliser solution
}

\author{
P RAFFERTY, R BEASLEY, S T HOLGATE \\ From the Immunopharmacology Group, Southampton General Hospital, Southampton
}

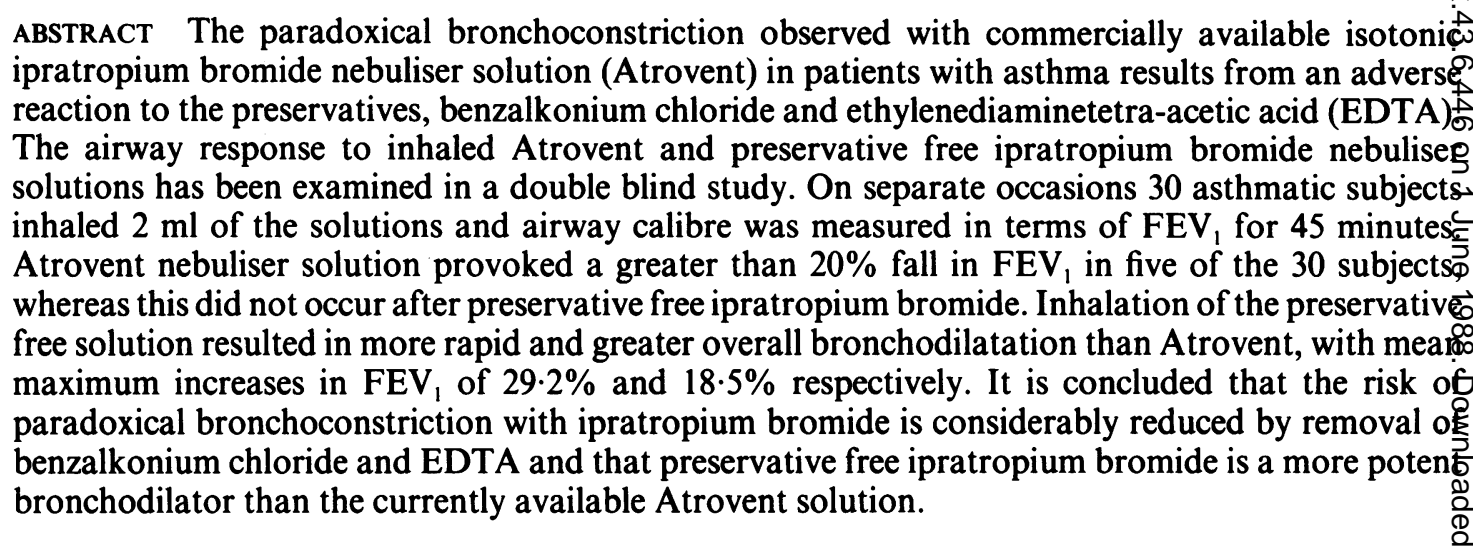

\section{Introduction}

Ipratropium bromide (Atrovent) administered for inhalation by pressurised metered dose aerosol has found wide use for the treatment of reversible obstructive airways disease. The drug is also available as a solution for nebulisation in patients with severe airflow limitation, though occasional paradoxical bronchoconstriction has been reported..$^{1-3}$ When the bronchoconstriction had been shown to be largely accounted for by the hypotonicity of the original nebulised solution ${ }^{4}$ this was reformulated as an isotonic solution. Despite this change occasional reports of bronchoconstriction still occur. ${ }^{5}$

In a single case study Patel et $a l^{5}$ suggested that bronchoconstriction with ipratropium bromide occurred as an idiosyncratic response to the bromide ion, but in a controlled study in patients who developed bronchoconstriction with hypotonic ipratropium bromide and sodium bromide administration of the solutions in the isotonic form failed to produce this response. ${ }^{6}$ In a further double blind, placebo controlled study in asthmatic subjects we have shown that both benzalkonium chloride and ethyl-

Address for reprint requests: Dr P Rafferty, Department of Respiratory Medicine, Western Infirmary, Glasgow G11 6NT.

Accepted 16 March 1988 enediaminetetra-acetic acid (EDTA), present i̊ํำ isotonic Atrovent as bacteriostatic and stabilising agents, cause bronchoconstriction. ${ }^{7}$ Benzalkoniun $\overrightarrow{\mathrm{D}}$ chloride caused bronchoconstriction at the concentra tion present in the nebuliser solution of $0.25 \mathrm{~g} / \mathrm{b}$ whereas EDTA caused bronchoconstriction only â concentrations more than twice that present in the nebuliser solution $(0.5 \mathrm{~g} / \mathrm{l})$. In this study about quarter of asthmatic subjects who inhaled Atroven from a starting volume of $4 \mathrm{ml}$ (that is, $1 \mathrm{mg}$ ipratropium bromide) developed immediate bronchoconstriction with a fall in forced expirator» volume in one second $\left(\mathrm{FEV}_{1}\right)$ of more than $20 \%$ fron baseline. When these subjects inhaled only isotonis preservative free ipratropium bromide bronchodilatation occurred. We have now investigated the effect of the maximum single dose of isotonic Atrovento recommended by the manufacturer $(2 \mathrm{ml}$-that is, 0.2 mg ipratropium bromide) on airway calibre in patiento with asthma and chronic bronchitis and compared its bronchodilator effect with that of preservative free ipratropium bromide.

\section{Methods}

PATIENTS

Thirty patients took part in the study and theis characteristics are described in table 1. All hag 
Table 1 Characteristics of the patients

\begin{tabular}{|c|c|c|c|}
\hline & All patients & Atopic & Non-atopic \\
\hline $\begin{array}{l}\text { Number } \\
\text { Age (mean (SEM)) } \\
\text { Sex (M:F) } \\
\text { No of smokers } \\
\text { No with chronic bronchitis* } \\
\text { FEV, } \% \text { predicted, } \\
\text { mean (SEM)) } \\
\text { PC } \text { methacholine }_{20} \text { (mg/ml) } \dagger \text { : mean } \\
\text { (range) }\end{array}$ & $\begin{array}{l}30 \\
54 \cdot 7(2 \cdot 7) \\
21: 9 \\
22 \\
15 \\
62 \cdot 4(5 \cdot 3)\end{array}$ & $\begin{array}{l}13 \\
47 \cdot 5 \pm 4 \cdot 1 \\
8: 5 \\
8 \\
3 \\
73 \cdot 7(9 \cdot 6)\end{array}$ & $\begin{array}{l}17 \\
60 \cdot 1 \pm 2 \cdot 9 \\
14: 4 \\
13 \\
12 \\
53 \cdot 8(4 \cdot 5)\end{array}$ \\
\hline
\end{tabular}

${ }^{*}$ Medical Research Council definition.

†Geometric mean.

documented reversible airways obstruction, having previously shown a greater than $15 \%$ improvement in $\mathrm{FEV}_{1} 15$ minutes after inhalation of $200 \mu \mathrm{g}$ of salbutamol. Twenty two of the patients were smokers, and 15 conformed to the Medical Research Council (MRC) definition of chronic bronchitis with chronic mucus hypersecretion, all being past or current smokers. All patients were receiving regular inhaled $\beta_{2}$ adrenoceptor agonists with or without inhaled corticosteroids or inhaled ipratropium bromide or both; these were withheld for 12 hours before each visit to the laboratory. The study was approved by the Southampton University Hospitals ethical subcommittee and written informed consent was obtained from each patient.

\section{STUDY DESIGN}

Subjects attended the laboratory on three separate occasions at least 48 hours apart. During the first two visits the patients received $2 \mathrm{ml}$ of either isotonic Atrovent nebuliser solution containing benzalkonium chloride $0.25 \mathrm{~g} / 1$ and EDTA $0.5 \mathrm{~g} / 1$ or isotonic preservative free ipratropium bromide by inhalation double blind and in random order. The solutions were nebulised at room temperature by compressed air with an Inspiron nebuliser (Bard, Sunnywell, Sunderland) with an output of $0.4 \mathrm{ml} / \mathrm{min}$ at a flow rate of $81 / \mathrm{min}$. The aerosol was inhaled through a mouthpiece. Two baseline measurements of $\mathrm{FEV}_{1}$ were made followed by inhalation of saline vehicle solution as five maximal inhalations from functional residual capacity. If the $\mathrm{FEV}_{1}$ had not fallen by more than $10 \%$ from baseline after three minutes Atrovent or preservative free ipratropium bromide solutions were administered during tidal breathing from a starting volume of $2 \mathrm{ml}$ with nebulisation to dryness. FEV 1 was measured immediately and at $2,5,10,15,30$, and 45 minutes after nebulisation. On the third visit the 26 patients whose baseline $F E V_{1}$ was greater than 1.0 litres underwent inhalation challenge with methacholine modified from the method described by Chai. ${ }^{8}$ Skinprick tests with six common allergens (house dust, Dermatophagoides pteronyssinus, cat, dog, feather, grass pollen, and a control solution-Bencard, Middlesex) were performed on all patients. A weal diameter of over $4 \mathrm{~mm}$ at 10 minutes in response to one or more allergens was considered a sign of atopy.

\section{DATA ANALYSIS}

Baseline $\mathrm{FEV}_{1}$ values were compared between study days by means of Student's $t$ test for paired data. FEV after nebulisation was expressed as a percentage of the post-saline baseline value and plotted against time. The airways response for the two ipratropium bromide solutions was assessed by comparing the maximum and minimum values of FEV, achieved, and the areas under the $F V_{1}$-time course curves (AUC) calculated by trapezoid integration. For each of the three variables comparisons were made between Atrovent nebuliser solution and preservative free ipratropium bromide, paired Student's $t$ tests being used for $(a)$ all patients and $(b)$ subgroups of patients divided on the basis of the presence or absence of atopy, smoking history, and the presence or absence of chronic bronchitis. Multiple linear regression analysis was used to investigate any relation between the airway response to the nebulised solutions and atopy, smoking, and chronic bronchitis.

The provocation concentration of methacholine causing a $20 \%$ fall in $\mathrm{FEV}_{1}\left(\mathrm{PC}_{20}\right)$ was derived from the concentration-response curve by linear interpolation. The relation between methacholine responsiveness $\left(\mathrm{PC}_{20}\right.$ methacholine) and the airway response to Atrovent and preservative free ipratropium bromide solutions were determined by linear regression analysis. Minitab ${ }^{9}$ was used for all statistical analyses.

\section{Results}

All patients completed the study. There was no significant difference between mean baseline $F E V_{1}$ on different treatment days. Inhalation of isotonic Atrovent caused initial bronchoconstriction with a fall in $\mathrm{FEV}_{1}$ of over $20 \%$ from baseline in five of the 30 subjects. Although nebulised Atrovent solution caused progressive bronchodilatation in most subjects (fig 1, table 2), the FEV, remained below the initial baseline value 45 minutes after inhalation in six subjects.

After inhalation of $2 \mathrm{ml}$ preservative free ipratropium bromide one subject showed an initial fall in $\mathrm{FEV}_{1}$ of $19 \%$, which returned to within $2 \%$ of baseline by 2 minutes. None of the other subjects showed a fall in $\mathrm{FEV}_{1}$ of more than $10 \%$. All subjects subsequently achieved bronchodilatation with this preparation (fig 1). The speed of onset and the degree of bronchodilatation was greater after preservative free ipratropium bromide than after Atrovent (fig 1, table 2). 


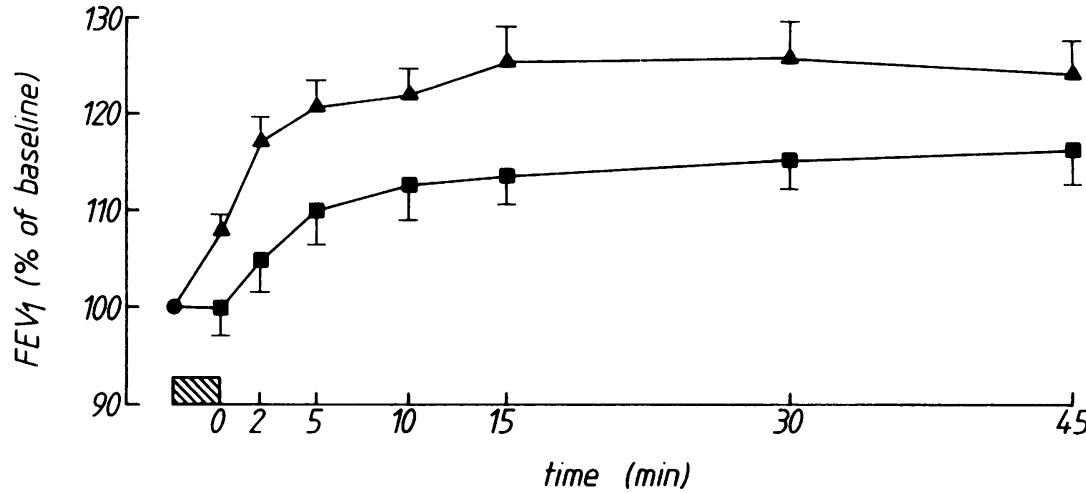

Fig 1 Effect of Atrovent (squares) and preservative free ipratropium bromide (triangles. on airway calibre in 30 subject means with standard errors.

time (min)

Bronchial responsiveness to inhaled methacholine was assessed in 26 subjects. There was no significant correlation between the $\log \mathrm{PC}_{20} \mathrm{FEV}_{1}$ methacholine and the airway response to either Atrovent or the preservative free solution.

There were no significant differences between smokers and non-smokers or between bronchitic and nonbronchitic patients in their response to either Atrovent or preservative free ipratropium bromide. There was, however, a difference in response between atopic and non-atopic subjects (fig 2, table 3). After Atrovent three of the 13 atopic subjects developed a fall in FEV of over $20 \%$ from baseline, compared with only two of 17 non-atopic subjects. Overall, Atrovent provoked a temporary fall (of $8.3 \mathrm{l}$ ) in $\mathrm{FEV}_{1}$ in atopic subjects, which was not seen in the non-atopic group $(p<0.05)$. Multiple linear regression confirmed that atopy was the strongest determinant of the bronchoconstrictor response to Atrovent solution. The difference between groups could not be attributed to the level of bronchial responsiveness, with geometric mean $\mathrm{PC}_{20} \mathrm{FEV}_{1}$ methacholine values of 0.24 and $0.36 \mathrm{mg} / \mathrm{ml}$ for the atopic and non-atopic subjects, a non-significant difference.

\section{Discussion}

This study shows that inhalation of $2 \mathrm{ml}$ isotonic Atrovent nebuliser solution, the maximum single dose recommended by the manufacturers, causes bronchoconstriction in an appreciable proportion of patients with reversible obstructive airways disease. In this group of patients selected at random from the outpatient department, five out of 30 patients ha substantial bronchoconstriction, defined as a fall if

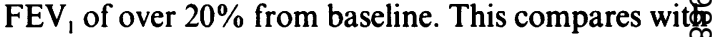
a previous study in which just over one in four patients with asthma had a similar degree of bronchoconstrie tion when challenged with $4 \mathrm{ml}$ Atrovent solution. 倡 the present study all patients had previously show reversibility of their airways obstruction by a\% improvement in $\mathrm{FEV}_{1}$ of over $15 \%$ with a adrenoreceptor agonist, and half also had symptom conforming to the MRC definition of chronic brow chitis with mucus hypersecretion. Nebulised Atroven caused bronchoconstriction in a similar proportion of patients with and without chronic bronchitis, and the changes were similar in magnitude to those observed in patients with more classical asthma without mucuss hypersecretion.

After inhalation of preservative free ipratropium bromide appreciable bronchoconstriction wa observed in only one subject and this was transient. In the absence of preservatives ipratropium bromide also proved more effective than Atrovent in producin bronchodilatation throughout the 45 minutes of the study, achieving almost double the change in FEF observed with Atrovent. The response to preservative free ipratropium bromide occurred more rapidly that

Table 2 Airway responses (means with standard errors in parentheses) to nebulised Atrovent and preservative free ipratropium bromide (PFIB) in the 30 patients

\begin{tabular}{|c|c|c|c|c|}
\hline & Atrovent & PFIB & $\begin{array}{l}\text { Difference } \\
\text { (PFIB-Atrovent) }\end{array}$ & $p^{*}$ \\
\hline \multirow{3}{*}{ 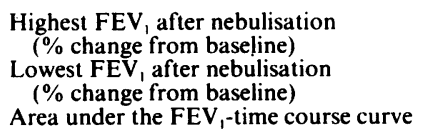 } & $18 \cdot 5(2 \cdot 8)$ & $29 \cdot 2(3 \cdot 6)$ & $10 \cdot 7(2.9)$ & $<0.001$ \\
\hline & $-3.5(2.2)$ & $5.5(2.0)$ & $9 \cdot 0(2 \cdot 5)$ & $<0.004$ \\
\hline & 565 (119) & $1030(145)$ & 465 (117) & $<0.0004$ \\
\hline
\end{tabular}




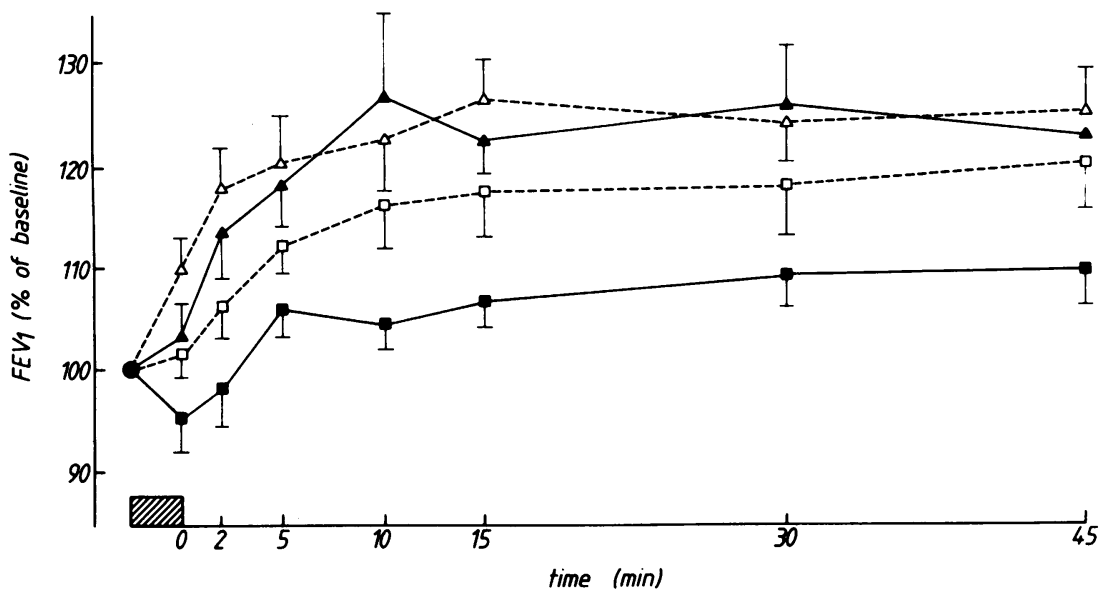

Fig 2 Effect of Atrovent (squares) and preservative free ipratropium bromide (triangles) in 13 atopic (closed symbols) and 17 non-atopic subjects (open symbols): means with standard errors.

to Atrovent, maximum bronchodilatation occurring at 30 minutes compared with 45 minutes (fig 1). We have previously shown that both benzalkonium chloride and EDTA may cause bronchoconstriction in patients with asthma, with a response lasting at least 45 minutes. In Atrovent therefore the bronchoconstrictor effects of the preservatives are likely to be competing with the bronchodilator action of ipratropium bromide, in some subjects the initial response being sufficient to cause bronchoconstriction.

A further insight into the possible mechanism or mechanisms by which benzalkonium chloride and EDTA may cause bronchoconstriction comes from observing the influence of atopy on the airways responses (fig 2). The bronchodilatation observed after inhalation of preservative free ipratropium bromide was similar in the two groups; in response to Atrovent the atopic subjects achieved less bronchodilatation than non-atopic subjects, though the difference was not significant. A fall in $\mathrm{FEV}_{1}$ of $20 \%$ or more was experienced by three of the 13 atopic subjects after Atrovent, but only transiently in two of the 17 non-atopic subjects. This reaction could not be

Table 3 Comparison of airway responses (means with standard errors in parentheses) to Atrovent in atopic and non-atopic subjects

\footnotetext{
$\begin{array}{llll}\text { Highest FEV, after nebulisation } \\ \text { (\% change from baseline) } & 14.0(2.9) & 22.0(4.3) & 0.13\end{array}$

Lowest FEV, after nebulisation

$\begin{array}{llll}(\% \text { change from baseline) } & -8.3(2.8) & 0.2(3.0) & <0.05\end{array}$

Area under the FEV,-time

$-8.3(2.8) \quad 0.2(3.0) \quad<0.05$

course curve

$311(121) \quad 759(177)<0.05$
}

*Student's $t$ test attributed to differences in non-specific bronchial responsiveness between the two groups and is likely to relate to the mechanism by which Atrovent provokes bronchoconstriction.

Benzalkonium chloride is composed of quaternary ammonium compounds and widely used as a bacteriocidal agent. Its molecular conformation contains both hydrophobic and cationic groups, which confer surface active properties thought to be responsible for its bacteriocidal activity. ${ }^{10}$ At concentrations above 3 $\mu \mathrm{g} / \mathrm{ml}$ it has been shown to stimulate histamine release in vitro from rat peritoneal mast cells. " Since it also causes histamine release from mast cells that have been "heat inactivated" (and hence are unresponsive to specific secretagogues such as $48 / 80$ ), this is thought to be a non-specific effect related to its surface active properties. At concentrations above $1 \mu \mathrm{g} / \mathrm{ml}$ benzalkonium chloride enhances IgE dependent release of the preformed mediator 5-hydroxytryptamine from rodent mast cells. ${ }^{12}$ Thus the presence of benzalkonium chloride in Atrovent, with its potential to serve as a mast cell secretagogue, may account for the greater bronchoconstriction observed in patients with atopic asthma, in whom mast cells obtained by bronchoalveolar lavage have been shown to be activated. ${ }^{13} \mathrm{~A}$ similar difference in bronchoconstrictor potency between atopic and non-atopic asthma has been observed after bronchial challenge with adenosine and adenosine $5^{\prime}$-monophosphate (AMP) ${ }^{14}$ agonists that also provoke bronchoconstriction by augmenting mediator release from preactivated bronchial mast cells. ${ }^{15}$

Innocenti has documented one patient in whom sensitisation to benzalkonium chloride resulted in more protracted asthma ${ }^{16}$ inhalation of benzalkonium chloride causing immediate bronchoconstriction, which persisted for at least five hours. Although the mechanism was not determined, preinhalation of 
sodium cromoglycate completely abolished the bronchoconstriction, suggesting that the immediate airway response may be mediated through a mast cell dependent mechanism. A similar mechanism might have been responsible for a recent case in which nebulised beclomethasone diproprionate containing benzalkonium chloride, in a concentration of $0.2 \mathrm{~g} / \mathrm{l}$, appeared to produce bronchoconstriction in asthmatic patients seven months after starting treatment. ${ }^{17}$

Bronchoconstriction by EDTA is thought to occur via a direct contractile effect on airway smooth muscle through calcium chelation. ${ }^{18}$ Although the concentration of EDTA required to produce bronchoconstriction under challenge conditions was at least twice that present in Atrovent nebuliser solution, this agent has been shown to increase non-specific bronchial responsiveness in Basenji greyhound dogs. ${ }^{18}$ An interaction between benzalkonium chloride and EDTA is therefore possible, with EDTA enhancing airway smooth muscle responsiveness to spasmogenic mediators released from mast cells by benzalkonium chloride.

We conclude that the currently marketed Atrovent nebuliser solution containing preservatives can produce bronchoconstriction in some patients, even when administered in the manufacturers' recommended dose. Bronchoconstriction was not observed when the two preservatives were removed from the solution, and preservative free ipratropium bromide proved to be considerably more effective as a bronchodilator agent than Atrovent. A recent study ${ }^{19}$ has reported an inverse relation between the incidence of bacterial contamination of nebuliser solutions and the presence of antibacterial agents in the solution, so removal of these preservatives might result in an increased incidence of bacterial contamination. Contamination would be less likely if the solution were prepared under sterile conditions in unit dose vials.

We thank Dr Sarah Morgan, Boehringer Ingelheim, for providing unit dose vials of preservative free ipratropium bromide, Dr C J Brophy for valuable advice, and Mrs Margaret Dowling for preparing the manuscript.

\section{References}

1 Connolly CK. Adverse reaction to ipratropium bromide. Br Med J 1982;285:934-5.

2 Jolobe OMP. Adverse reaction to ipratropium bromide. Br Med J 1982;285:1425-6.
3 Howarth PH. Bronchoconstriction in response ipratropium bromide. Br Med J 1983;286: 1825-6.

4 Mann JS, Howarth PH, Holgate ST. Bronch constriction induced by ipratropium bromide asthma: relation to hypertonicity. $\mathrm{Br} \mathrm{Med}$ 1984;289:469.

5 Patel KR, Tullet WM. Bronchoconstriction in response to ipratropium bromide. $\mathrm{Br}$ Med J 1983;286:1318.

6 Rafferty P, Beasley R, Howarth PH, Mann JS, Holgate ST. Bronchoconstriction induced by nebulised ipratropium bromide: relation to the bromide ion. 础 Med J 1986;293:1538-9.

7 Beasley R, Rafferty P, Holgate ST. Bronchoconstrictơ properties of preservatives in ipratropium bromide (Atrovent) nebuliser solution. Br Med J 1987;29: $1197-8$.

8 Chai H, Farr RS, Froehlich LA, Mathison DA, McLea苚 JA, Rosenthal RR, Sheffer AL, Spector SL, Townle RG. Standardisation of bronchial inhalation challenge procedures. J Allergy Clin Immunol 1975;56:323-7. C

9 Joiner BL, Ryan BF, Ryan TA. Minitab handboo Boston, Mass: PSW Publishers, Duxbury Press, 1985.

10 Harvey SC. Antiseptics and disinfectants: fungicides ectoparasiticides. In: Goodman LS, Gilman A, eds़ The pharmacological basis of therapeutics. New York MacMillan, 1981:978-9.

11 Read GW, Kiefer EF. Benzalkonium chloride: selectivo inhibitor of histamine release induced by compoun 48/80 and other polyamines. J Pharmacol Exp The 1979;211:711-5.

12 Coleman JW, Holgate ST, Church MK, Godfrey RC Immunoglobulin E decapeptide-induced 5-hydrox $\mathrm{B}$ triptamine release from rat peritoneal mast cells Biochem J 1981;198:615-9.

13 Tamaika M, Ida S, Yirke S, Ishizaka T, Takishima $\mathrm{F}$. Mast cells in bronchoalveolar lumen of patients wit bronchial asthma. Am Rev Respir Dis 1984;129:1000-

14 Phillips G, Rafferty P, Beasley R, Holgate ST. The contribution of histamine release to AMP induced bronchoconstriction in non-allergic asthma [abstracti Thorax 1987;42:218.

15 Rafferty P, Beasley R, Holgate ST. The contribution of histamine to bronchoconstriction produced by inhaleg allergen and adenosine 5 'monophosphate in asth matics. Am Rev Respir Dis 1987;136:369-73.

16 Innocenti A. Asma professionale da benzalconio clorur, Med Lav 1978;69:713-5.

17 Clark RJ. Exacerbation of asthma after nebulised beclomethasone diproprionate. Lancet 1986;ii:574-5. N

18 Downes $\mathrm{H}$, Hirshman CA. Calcium chelators increasé airway responsiveness. J Appl Physiol 1985;59:92-5. 음

19 Barnes KB, Clifford R, Murphy D, Comber P, Bell Holgate ST. Bacterial contamination of home nebu傮 isers. $\mathrm{Br}$ Med $\mathrm{J}$ (in press).

\section{,}

